\title{
Multiple cranial nerve palsies due to perineural invasion
}

Figure 1 Cavernous sinus thickening
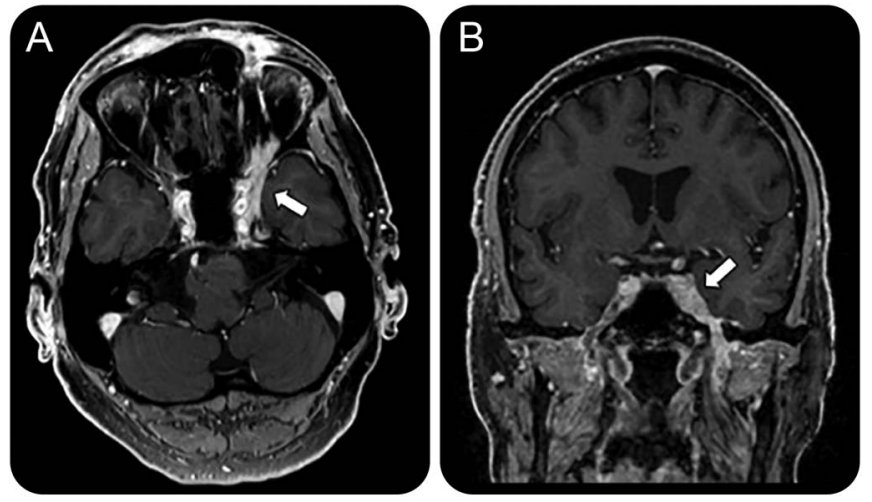

Postcontrast T1-weighted MRI reveals thickening and enhancement of the external wall of the left cavernous sinus (arrows). (A) Axial; (B) coronal.

A 69-year-old man presented with a recent history of painless diplopia and left eye conjunctival injection. He had a cutaneous adenosquamous carcinoma removed from the left forehead 3 years before. The examination showed complete left ophthalmoplegia, exophthalmos, ptosis, and ipsilateral V1 hypoesthesia. Brain MRI revealed thickening and contrast enhancement of the external wall of the left cavernous sinus (figure 1).

Figure 2 Perineural spread

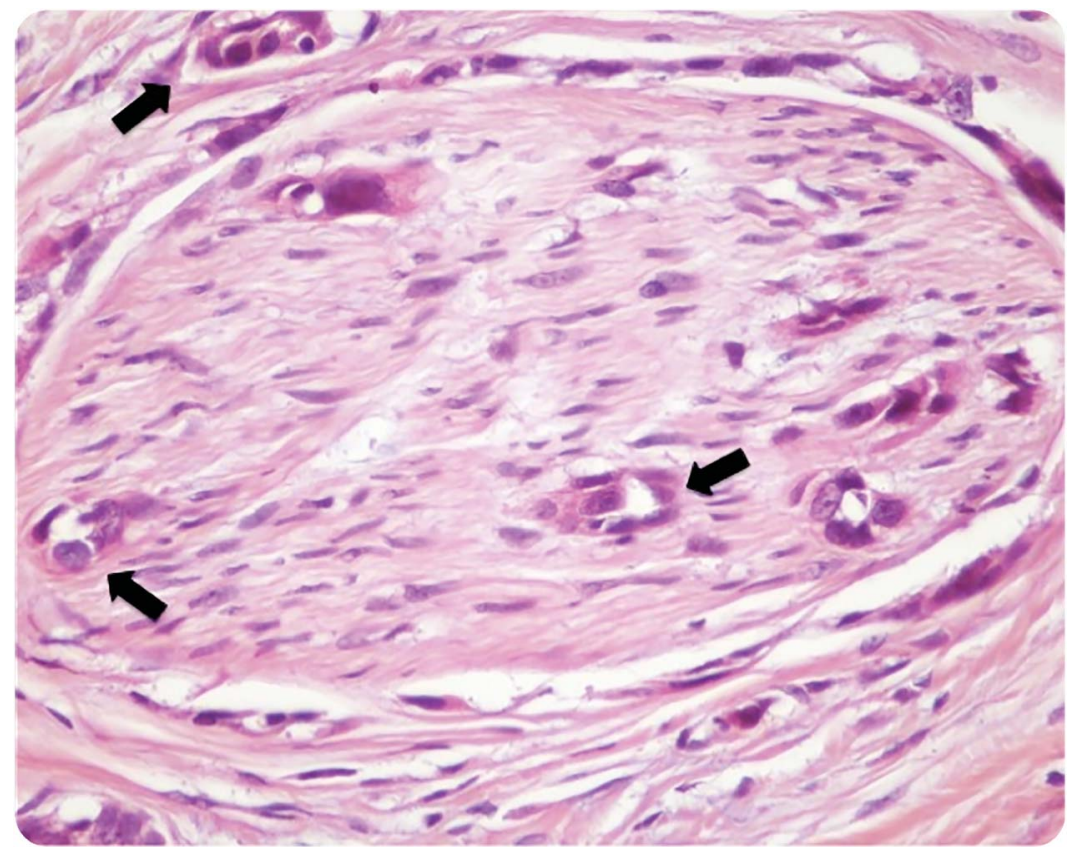

Histopathology of the adenosquamous skin tumor demonstrates perineural and intraneural invasion (arrows). Hematoxylin \& eosin, $\times 400$. 
Because of skin cancer history, biopsy specimens of the previously resected tumor were reassessed, exhibiting neoplastic perineural spread (figure 2). Cavernous sinus invasion due to centripetal perineural spread from a supposedly removed skin cancer has been previously reported. ${ }^{1,2}$

Anibal Chertcoff, MD, Nicolás Morera, MD, Fátima Pantiu, MD, Julieta Quiroga Narváez, MD,

Félix Vigovich, $M D$, Ricardo Reisin, $M D$

From the Departments of Neurology (A.C., N.M., F.P., J.Q.N., R.R.) and Pathology (F.V.), British Hospital of Buenos Aires, Argentina.

Author contributions: Aníbal Chertcoff: drafting/revising the manuscript, analysis or interpretation of data, accepts responsibility for conduct of research and final approval, acquisition of data, image processing. Nicolás Morera: study concept or design, accepts responsibility for conduct of research and final approval, study supervision. Fátima Pantiu: drafting/revising the manuscript, analysis or interpretation of data, accepts responsibility for conduct of research and final approval, acquisition of data. Julieta Quiroga Narváez: drafting/revising the manuscript, analysis or interpretation of data, accepts responsibility for conduct of research and final approval, acquisition of data. Félix Vigovich: drafting/revising the manuscript, analysis or interpretation of data, accepts responsibility for conduct of research and final approval, acquisition of data. Ricardo Reisin: drafting/revising the manuscript, study concept or design, accepts responsibility for conduct of research and final approval.

Study funding: No targeted funding reported.

Disclosure: The authors report no disclosures relevant to the manuscript. Go to Neurology.org for full disclosures.

Correspondence to Dr. Chertcoff: anibalchertcoff@gmail.com

1. Woodruff WW Jr, Yeates AE, McLendon RE. Perineural tumor extension to the cavernous sinus from superficial facial carcinoma: CT manifestations. Radiology 1986;161:395-399.

2. Grimm AR, Baird M, Khan M, Pitman KT. Perineural spread to the cavernous sinus from cutaneous SCCa. Laryngoscope 2010; 120(suppl 4):S150.

\section{WriteClick ${ }^{\circledR}$ rapid online correspondence}

Have a comment on a recent Neurology ${ }^{\circledR}$ article you would like to share? Now it is easier and more convenient. Neurology.org has launched WriteClick on the home page and sidebars of each article to encourage remarks and debate among users.

WriteClick is restricted to comments about studies published in Neurology within the last eight weeks.

Learn more at Neurology.org/letters

\section{Complimentary CME and Self-assessment Resources: An Exclusive AAN Membership Benefit!}

Looking for ways to earn important CME credits in 2016? Look no further, because AAN membership provides FREE* access to the AAN's suite of online learning programs: NeuroSAE ${ }^{\circledR}$, NeuroLearn ${ }^{\mathrm{SM}}$, and NeuroPI ${ }^{\mathrm{SM}}$. Access from virtually anywhere-home or office-to meet your CME needs, as well as take the necessary steps toward fulfilling your maintenance of certification (MOC) requirements, as mandated by the ABPN. Visit AAN.com/view/MOC today!

*Free access is limited to one course per program at a time. 


\title{
Neurology
}

\author{
Multiple cranial nerve palsies due to perineural invasion \\ Aníbal Chertcoff, Nicolás Morera, Fátima Pantiu, et al. \\ Neurology 2016;86;1645-1646 \\ DOI 10.1212/WNL.0000000000002615
}

\section{This information is current as of April 25, 2016}

\section{Updated Information \& Services}

\section{References}

Subspecialty Collections

\section{Permissions \& Licensing}

Reprints including high resolution figures, can be found at: http://n.neurology.org/content/86/17/1645.full

This article cites 2 articles, 0 of which you can access for free at: http://n.neurology.org/content/86/17/1645.full\#ref-list-1

This article, along with others on similar topics, appears in the following collection(s):

Cranial neuropathy

http://n.neurology.org/cgi/collection/cranial_neuropathy Eyelids

http://n.neurology.org/cgi/collection/eyelids

MRI

http://n.neurology.org/cgi/collection/mri

Nerve tumor

http://n.neurology.org/cgi/collection/nerve_tumor

Ocular motility

http://n.neurology.org/cgi/collection/ocular_motility

Information about reproducing this article in parts (figures,tables) or in its entirety can be found online at:

http://www.neurology.org/about/about_the_journal\#permissions

Information about ordering reprints can be found online:

http://n.neurology.org/subscribers/advertise

Neurology ${ }^{\circledR}$ is the official journal of the American Academy of Neurology. Published continuously since 1951, it is now a weekly with 48 issues per year. Copyright @ 2016 American Academy of Neurology. All rights reserved. Print ISSN: 0028-3878. Online ISSN: 1526-632X.

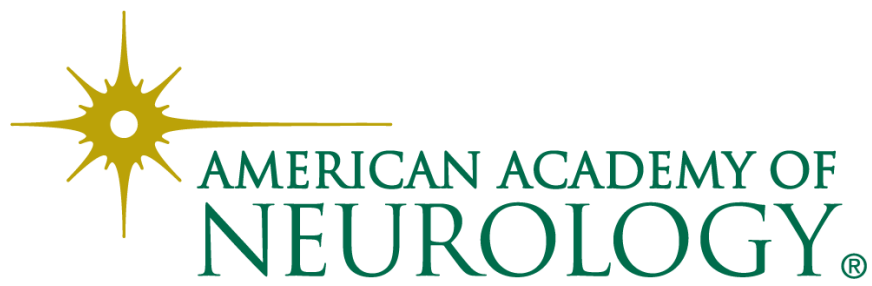

